\title{
GLASBENA USTVARJALNOST IN POUSTVARJALNOST VALVASORJEVIH POTOMCEV NA SLOVENSKEM V 19. IN PRVI POLOVICI 20. STOLETJA
}

\author{
BORIS GOLEC \\ Znanstvenoraziskovalni center SAZU, Ljubljana
}

\begin{abstract}
Izvleček: Prispevek obravnava do nedavna neznane potomce kranjskega polihistorja Janeza Vajkarda Valvasorja (1641-1693), tako ali drugače povezane z glasbeno ustvarjalnostjo in poustvarjalnostjo $v$ slovenskem prostoru. Pripadali so zadnjim na Slovenskem živečim generacijam polihistorjevega rodu in izšli iz vseh treh vej Valvasorjevega potomstva, ki so se razdelile v sedemdesetih letih 18. stoletja. Sredi 19. stoletja so se skoraj vsi njihovi člani preselili s slovenske Štajerske v Gradec, toda prav vsi, ki so se dokumentirano ukvarjali z glasbo, so vsaj del življenja preživeli na Slovenskem. Razvejano potomstvo Janeza Vajkarda Valvasorja (do danes okoli 250 oseb) je od vseh umetnosti najbolj povezano prav z glasbeno.
\end{abstract}

Ključne besede: Valvasor, baroni Dienersperg, vitezi Gadolla, Rudolf von Weis-Ostborn, skladatelji Ipavci

\begin{abstract}
The article deals with the until-recently unknown descendants of the Carniolan polymath Janez Vajkard Valvasor (1641-1693) that were connected one way or another to music production and reproduction in the Slovenian territory. They belonged to the last generations of the polymath's family to live in the Slovenian territory, stemming from all three branches of Valvasor's descendants that split in the 1770. In the mid-nineteenth century nearly all their members moved from Slovenian Styria to Graz, but each and everyone who has been documented to have engaged in music had spent at least part of their lives in the Slovenian territory. Music was the art to which the branched-out descendants of Janez Vajkard Valvasor (about 250 persons to date) have been most closely connected.
\end{abstract}

Keywords: Valvasor, Dienersperg barons, knights of Gadolla, Rudolf von Weis-Ostborn, composers of the Ipavec family

Četudi kranjski polihistor Janez Vajkard Valvasor (1641-1693) v slovenski glasbeni zgodovini nima posebnega mesta - na njegovo Slavo vojvodine Kranjske (1689) se v zvezi z glasbo opirata predvsem folkloristika ter glasbeno narodopisje ${ }^{1}-$, želim s pričujočim

1 Prim. Peter von Radics, Johann Weikhard Freiherr von Valvasor (geb. 1641, gest. 1693). Mit 5 Porträts und 15 anderen Abbildungen; samt Anhang, Nachtrag und der Genealogie der Familie Valvasor (Ljubljana: Krainische Sparkasse, 1910), 147-149; Igor Cvetko, »Valvasor in njegov zvok, «Valvasorjev zbornik: Ob 300 letnici izida Slave vojvodine Kranjske: Referati s simpozija v Ljubljani 1989, ur. Andrej Vovko, (Ljubljana: Slovenska akademija znanosti in umetnosti, 1990), 311-322. 
prispevkom opozoriti na tiste nedavno odkrite Valvasorjeve potomce, ki so bili tako ali drugače povezani z glasbeno ustvarjalnostjo in poustvarjalnostjo našega prostora. Pripadali so zadnjim na Slovenskem živečim generacijam polihistorjevega rodu. Z znamenitim prednikom jih res ne povezuje veliko več kot genealoška vez in vrhu tega za svoje sorodstvo z Valvasorjem po večini niti niso vedeli. Dejstvo, da je šlo za neposredne potomce ene naših najznamenitejših osebnosti zgodnjega novega veka ter kulturne in znanstvene zgodovine nasploh, se torej kaže predvsem kot zanimivost, vendar po drugi strani ne gre prezreti, da je razvejano potomstvo J. V. Valvasorja (skupaj okoli $250 \mathrm{oseb}$ ) od vseh umetnosti najbolj povezano prav z glasbeno. ${ }^{2}$

Vse tri rodbinske veje Valvasorjevih potomcev, ki so preživele do 20. stoletja - leta 1936 izumrla Dienerspergova ter še živeči Gadollova in Resingenova - so izšle iz otrok ene same osebe, polihistorjevega pravnuka Avguština barona Dienersperga (1742-1814), in v vseh treh so izpričani glasbeno usmerjeni ljudje, katerih življenjske poti so vrhu tega vsaj deloma povezane s slovenskim ozemljem. Skoraj vsi Valvasorjevi potomci so se sicer sredi 19. stoletja preselili s slovenske Štajerske v Gradec, a je še vse do leta 1941 vsaj kakšen prebival tudi na Slovenskem. Rodbina Gadolla, iz katere je izšel zadnji med njimi, živi v slovenski glasbeni in kulturni zgodovini zaradi povezanosti s šentjursko rodbino skladateljev Ipavcev, Resingenova rodbinska veja, prav tako povezana z Ipavci, pa je dala priznanega štajerskega skladatelja Rudolfa von Weis-Ostborna (1876-1962, Gradec), ki je v drugem desetletju 20. stoletja deloval v Ljubljani in je sploh kot zadnji iz Valvasorjevega rodu živel v rodnem mestu svojega prednika, kranjskega polihistorja.

Rod Janeza Vajkarda Valvasorja je zdaj dobro raziskan, ni pa mogoče reči, da zadovoljivo poznamo nagnjenja in darove posameznikov, še zlasti ne za prve štiri ali pet generacij, do prve polovice 19. stoletja. Relevantne vire prve roke o življenjskem slogu polihistorjevih potomcev predstavljajo za celotno 18. stoletje pravzaprav le njihovi zapuščinski inventarji (popisi premične in nepremične zapuščine). Žal so ohranjeni samo inventarji edine Valvasorjeve hčerke, katere rod se je nadaljeval do danes (1755), obeh njenih hčerk (1769 in 1786) ter duševno obolelega vnuka grofa Paradeiserja (1789), čigar zapuščino so popisali že 34 let pred njegovo smrtjo (u. 1823), toda niti v enem inventarju ne najdemo najmanjšega namiga na kakršno koli zanimanje za glasbo. ${ }^{3}$ Glede na izpovedno omejenost inventarjev in njihovo slabo ohranjenost, saj jih za veliko večino Valvasorjevih potomcev nimamo, seveda ni mogoče dajati nikakršnih sodb o tem, kakšno

2 O celotnem Valvasorjevem potomstvu gl. Boris Golec, »Valvasorjevo neznano potomstvo do današnjih dni,«Zgodovinski časopis 62 (2008): 351-383 (1. del); Zgodovinski časopis 65 (2011): 292-373 (2. del); Zgodovinski časopis 66 (2012): 46-114 (3. del).

3 Zapuščinski inventarji Valvasorjeve hčerke Regine Konstancije Dienersperg, roj. Valvasor (Arhiv Republike Slovenije (= ARS), AS 309, Zbirka zapuščinskih inventarjev Deželnega sodišča v Ljubljani, šk. 18, fasc. XI, D-25, 25. 2. in 7. 3. 1755), vnukinje Marije Ksaverije baronice Gall pl. Gallenstein, roj. Dienersperg (prav tam, šk. 39, fasc. XX, G-164, 17. 7. 1786), pravnuka Lovrenca Regulata grofa Paradeiserja (prav tam, šk. 92, fasc. XXXVIII, P-215, 1. 8. 1789) in vnukinje Jožefe Katarine Dienersperg, roj. Dienersperg (Steiermärkisches Landesarchiv, Gradec (= StLA), A. Dienersperg, K 2, H 49, 21. 8. 1769). Obsežen je zlasti inventar zapuščine izobraženega grofa Paradeiserja, a med številnimi predmeti in knjigami tudi v njem ni najti ničesar povezanega $\mathrm{z}$ glasbo. 
vlogo je imela glasba v življenju posameznikov njegovega rodu v 18. stoletju. Inventarje štirih polihistorjevih potomcev sem omenil tudi zato, ker enak vir, inventar zapuščine Janeza Vajkarda Valvasorja (1694), vendarle navaja nekaj glasbenih instrumentov. ${ }^{4} \breve{C}$ Valvasor ne bi zapustil Slave vojvodine Kranjske, bi bil popis njegove zapuščine sploh edini dokaz, da ga je instrumentalna glasba vsaj zanimala, če ni kar sam igral katerega od popisanih instrumentov.

\section{Dienerspergova rodbinska veja - pozabljeni in zapravljeni glasbeni talenti?}

Dienerspergovo rodbinsko vejo Valvasorjevega potomstva v ožjem pomenu besede je zasnoval polihistorjev prapravnuk Franc Ksaver baron Dienersperg (1773, Dobrna - 1846, Gradec), v širšem smislu pa je njena začetnica Regina Konstancija Valvasor (ok. 1690, neznano kje, u. 1755, Novo mesto), najmlajša hči Janeza Vajkarda Valvasorja, poročena pl. Dienersperg. Od šestih preživelih otrok kranjskega polihistorja je ta pred nekaj leti ponovno odkrita pozabljena hči edina imela vnuke in nadaljnje potomce. Z njenima hčerkama se je Valvasorjevo potomstvo razdelilo na kranjsko vejo - grofe Paradeiser, ki je izumrla leta 1823 v Ljubljani, in štajersko vejo - pl. Dienersperge, saj se je tudi njena hči Jožefa (1712, Volavče pri Šentjerneju, u. 1769, Ponikva) omožila v Dienerspergovo rodbino, in sicer na graščino Ponikva pri Celju. Leta 1766, že po moževi smrti, je dočakala pobaronjenje svojih devetih sinov, toda le eden od teh, že omenjeni Avguštin baron Dienersperg (1742, Ponikva pri Celju - 1814, Zg. Lanovž pri Celju), je imel legitimne otroke in je prednik vseh danes živečih Valvasorjevih potomcev (v začetku leta 2011 jih je živelo 107). Sreči in razsodnosti gre zasluga, da ta rod ni ugasnil že leta 1772; Avguštin je namreč s svojo mlado družino dobesedno pobegnil iz starega in dotrajanega gradu Dobrna, ki se je nenadoma začel podirati. V dolini pod gradom je nato zrastla nova dobrnska graščina, od Avguštinovih petih odrastlih otrok pa so Valvasorjev rod nadaljevali trije: sin Franc Ksaver, hči Barbara, por. pl. Gadolla, in hči Terezija, por. pl. Resingen. Rodbina sina Franca Ksaverja (1773-1846), ki je podedoval dobrnsko gospostvo z zdraviliščem, je po moški strani izumrla z zadnjim baronom Dienerspergom leta 1905 v Budimpešti, po ženski pa leta 1936 v Gradcu. ${ }^{5}$

Da je bil Dienerspergov rod povezan z glasbo, je znano šele za čas od tridesetih let 19. stoletja dalje. Gre sicer zgolj za nekaj drobnih podatkov, ki pa, povezani v celoto, dajejo slutiti, da je imela glasba v Dienerspergovi rodbini vendarle posebno mesto. Najzgodnejše poročilo o tem, četudi zelo skromno, dolgujemo dobrnskemu graščaku Francu Ksaverju, precej lirični in v mladosti močno ranjeni duši. V svojih spominih, napisanih v letih 1835-1836, je med vzroki, zaradi katerih se je v tem času skupaj z družino preselil z Dobrne v Gradec, navedel tudi glasbeno izobrazbo dveh svojih hčerk: »Razlog, da sem se z družino preselil v Gradec, je predvsem ta, da bi najinega najstarejšega sina [Ferdinanda],

4 V popisu Valvasorjeve zapuščine $\mathrm{v}$ Krškem se je znašlo sedem lesenih piščali, od tega pet obitih z medenino, nov fagot, dve harfi, od teh ena obita z medenino, dva velika in trije majhni francoski šalmaji (Schalmeipfeiffen aus Frankreich) ter dve dudi (Radics, Johann Weikhard Freiherr von Valvasor, 149; Cvetko, »Valvasor in njegov zvok, «311).

5 Golec, »Valvasorjevo neznano potomstvo« (3. del), 75-82. 
ki je napredoval v višje šole, lahko imela [s soprogo] pod starševskim vodstvom, dvema mlajšima hčerkama, Idi in Mari, pa omogočila primeren pouk francoščine, plesa in igranja klavirja, ter končno, da ne bi pogrešali zdravniške pomoči, ki nam je v Celju povsem manjkala.« ${ }^{6}$ Mlajši hčerki Ida (1819-1894) in Marija - Mari (1824-1890), tedaj stari 16 in 11 let, naj bi torej plesali in igrali klavir, kar je sicer spadalo v standardno damsko vzgojo in izobrazbo, primerno njunemu stanu. Njuni nadaljnji življenjski poti poznamo le v osnovnih potezah. Zanimivo je, da sta obe umrli približno v istem času v Celju, Marija kot vdova po tržaškem gubernijskem uradniku, potem ko je z edino odrastlo hčerko zapustila Trst, njena starejša sestra Ida, ki je večino življenja preživela v Gradcu, pa po (neformalni) ločitvi od svojega neplemiškega moža. ${ }^{7}$

Bežna omemba v spominih barona Dienersperga, da sta dve njegovi odraščajoči hčerki igrali klavir, zaživi v drugačni luči ob naslednjem dragocenem podatku. Njegova vnukinja Antonija baronica Dienersperg (1855, Gradec - 1908, Kog pri Ormožu), hči zadnjega sina Antona Aleksa, je bila prva glasbeno izobražena oseba v Valvasorjevem rodu sploh. Kot je k spominom njenega deda in očeta po njeni smrti pripisal Antonijin mož Ludvik Kofler (1843-1914), je pred poroko končala konservatorij na Dunaju. To je obenem vse, kar o njeni izobrazbi vemo. Na Dunaju se je s Koflerjem, Ptujčanom iz znane meščanske rodbine, tudi poročila, nato pa sta se zakonca z edinim sinom Ludvikom Koflerjem ml. (1876-1914) po krajšem bivanju v Gradcu preselila na Koflerjevo posestvo na Kogu pri Ormožu, kjer so vsi trije pomrli v kratkem časovnem razponu med letoma 1908 in 1914. O njihovem bivanju v zakotju Slovenskih goric, ki je trajalo več kot tri desetletja, je sicer znanega komaj kaj. Kot priča zemljiška knjiga, je Ludvik ml. živel razsipno in neurejeno življenje, kar tudi pojasnjuje, zakaj je neporočen in v komaj 37. letu umrl za vodenico. ${ }^{8} \mathrm{~V}$ spominu družine Breznik, poznejših lastnikov Koflerjeve posesti, danes še živita priimek Kofler in luksuzna oprema njihovega doma, med katero poleg velike knjižnice, krasnih slik, porcelana in srebrnega pribora ni manjkal koncertni klavir. ${ }^{9}$

Kdo na Kogu je poslušal zvoke te pozneje onemele priče na pozabljene čase, je mogoče le ugibati, kakor tudi to, ali je glasbeno izobražena gospa Antonija Kofler, rojena baronica Dienersperg, razveseljevala občinstvo na javnih nastopih. O tem je morda kdaj poročalo štajersko časopisje, a dosedanje iskanje morebitnih zapisov o Antonijinem koncertiranju ni dalo rezultatov. Glede na to, da ob njeni smrti v časopisju zaman iščemo vsaj kratek nekrolog, kakršne so sicer namenjali tudi v javnosti manj znanim pokojnikom, pa vse kaže, da je njena družina živela bolj odmaknjeno. Zanesljivo je bilo tako zadnja leta, ki jih je zaznamovalo nezgledno početje edinega sina. Antonijina polsestra Maria Sonnewend

6 Boris Golec, »Trpljenje 'celjskega Wertherja', tosvetne skrbi njegovega sina in uvod v zaton njunega rodu: Spomini dveh Valvasorjevih potomcev baronov Dienersperg s Celjskega, « Zgodovina za vse 18, št. 1 (2011): 33.

7 Prav tam, 55-56.

8 Prav tam, 59-60; Boris Golec, »'Der Hudič ist hier zu Hause' - med uboštvom, glasbo, portreti neznanih prednikov, shizofrenijo in evtanazijo. Usode zadnjih Valvasorjevih potomcev na Slovenskem v prvi polovici 20. stoletja in njihova kulturno-umetnostna zapuščina, « Zgodovina za vse 17 (2010): 67-70.

9 Pričevanje Božene Kramberger, roj. Breznik, iz Lendave, ki mi ga je v pismu 6. oktobra 2009 posredovala njena sestra Breda Farkaš Breznik, zdravnica iz Radencev. 
Spomini rodbine Dienersperg, ki so jih pisale tri roke, so edino pričevanje o glasbeni izobrazbi članov te izumrle veje Valvasorjevega potomstva (ZAP, ZAP 70, Rokopisna zbirka, R-45).

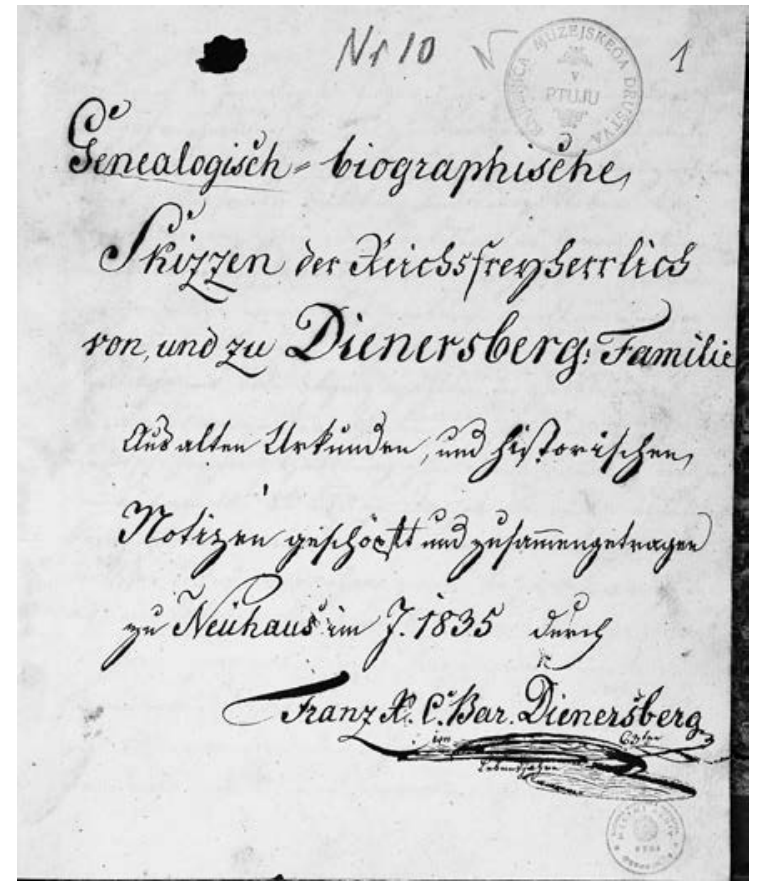

(1847-1895) je bila sicer poročena z ormoškim odvetnikom dr. Ivanom Geršakom (1838-1911), celih štirideset let stebrom tamkajšnjega slovenstva. A ker Geršak v svojih objavljenih spominih skorajda ni pisal o družini in zasebnem življenju, ${ }^{10}$ ni ženinih sorodnikov z bližnjega Koga niti omenil.

V slovensko kulturno zgodovino v širšem smislu so se Koflerji in njihova hiša zapisali po zaslugi umetnostnega zgodovinarja Franceta Steleta in poznejšega lastnika Koflerjeve posesti Jožefa Breznika, ki je leta 1934 Narodnemu muzeju v Ljubljani na Steletovo pobudo prodal galerijo starih portretov iz Koflerjeve oziroma Dienerspergove zapuščine. ${ }^{11}$ Portreti - med njimi oljna slika Valvasorjeve dolgo pozabljene hčerke Regine Konstancije, iz katere je izšlo vse današnje potomstvo ${ }^{12}$ - so prišli na Kog z očetom Antonije Kofler, Antonom Aleksom baronom Dienerspergom (1820, Dobrna - 1889, Ormož), ki je tu kot vdovec preživel zadnja leta svojega življenja. Temu sanjaškemu obubožanemu baronu,

${ }^{10}$ Ivan Geršak, Ormoški spomini: Ob petindvajsetletnici Ormoške posojilnice in ob tridesetlenici svojega beležništva v Ormožu (Ljubljana: Ormoška posojilnica, 1902), 9.

${ }^{11}$ Golec, »'Der Hudič ist hier zu Hause',« 71-72.

${ }^{12}$ Po spominih Breznikovega sina Bogomila (1911-1999) so imeli portretiranko za »Valvasorjevo sestro« (prav tam, 72). Ime Regine Konstancije, konec 19. stoletja že znane kot Valvasorjeve hčerke, je namreč medtem poniknilo v pozabo, predvsem zato, ker se je rodila po objavi Valvasorjevega rodovnika v Slavi vojvodine Kranjske leta 1689. Boris Golec, »Neznano in presenetljivo o življenju, družini, smrti, grobu in zapuščini Janeza Vajkarda Valvasorja, « Zgodovinski časopis 61 (2007): 312-313. 
ljubiteljskemu pesniku, risarju in slikarju, ni bilo dano - kot je sam zapisal v nadaljevanju očetovih spominov -, da bi poklicno udejanil ljubezen do tehnike, ampak je po volji drugih postal neuspešen, nesrečen častnik in je zgodaj na lastno pest slekel častniško uniformo. Zdi se, da so mu napake njegovega očeta in deda v vzgoji otrok zelo pomagale pri osebnem zorenju in vzgoji lastnega naraščaja. Gre mu namreč nesporna zasluga, da je hčerki Antoniji kljub skromnim materialnim možnostim omogočil študij na dunajskem konservatoriju. Z ženo sta se iz Gradca celo za nekaj let preselila v prestolnico, da sta lahko spremljala hčerkino šolanje. ${ }^{13}$

\section{Gadollova rodbinska veja, »zaslužna« za skladatelje Ipavce}

Veliko bolj kot Dienerspergi so v slovenski kulturni zgodovini navzoči vitezi Gadolla, rodbina, ki sta jo zasnovala Valvasorjeva prapravnukinja Barbara baronica Dienersperg (1772, Dobrna - 1841, Blagovna pri Šentjurju) in njen vsestransko razgledani soprog, doktor prava Johann Gadolla (1757, Gradec - 1832, Blagovna), sin graškega trgovca, pred poroko povzdignjen v viteza (1784) in štajerskega deželana (1785). ${ }^{14}$ Blagovenska graščina, kjer sta si zakonca ustvarila družino in dom, je vstopila v zavest kulturne in glasbene javnosti zaradi njunega znanstva z družino skladateljev Ipavcev, tem bolj ker sta oče Johann in sin Franc vitez Gadolla (1797, Blagovna - 1866, Gradec) ovekovečena v televizijski nadaljevanki Ipavci (1976). ${ }^{15}$ Po pravici, kajti, najsi se sliši še tako nenavadno, vendarle drži, da skladateljev Ipavcev brez Gadollovih preprosto ne bi bilo. Pri Gadollovih na Blagovni sta se namreč seznanila šentjurski ranocelnik Franc Ipavec in Dunajčanka Katarina Schweighoffer, starša skladateljev Alojza, Benjamina in Gustava Ipavca. Katarinina mati je po obubožanju svoje družine, leta 1811, prišla na spodnještajersko podeželje za vzgojiteljico Gadollovih odraščajočih otrok, Katarina pa je bila na Blagovni družabnica, dokler se ni leta 1814 omožila z Ipavcem. ${ }^{16}$ O Katarini Ipavec je Janko Barle skoraj sto let pozneje zapisal: »Ipavčeva žena - postavna in lepa gospa - je bila glasbeno zelo nadarjena in naobražena. Igrala je izvrstno glasovir in harfo. To je igrala tako dovršeno, da jo je hotel učitelj, pri katerem se je učila, vzeti s seboj na glasbeno potovanje. . $^{17}$

»Č́udodelni padar« Ipavec je kmalu po prihodu v Šentjur (1805) postal osebni zdravnik Johanna viteza Gadolle in njun odnos naj bi bil po tradiciji celo prijateljski. ${ }^{18}$

${ }^{13}$ Golec, »Trpljenje 'celjskega Wertherja',« 56-59.

${ }^{14}$ Golec, »Pozabljeni 'mali štajerski Valvasor',« 237-238; Golec, »Valvasorjevo neznano potomstvo« (3. del), 47-58.

${ }^{15}$ Fran Žižek, Ipavci (1. del, »Franc«), televizijska nadaljevanka (RTV Ljubljana, 1976). - Franca viteza Gadollo je igralsko upodobil Janez Albreht, njegovega očeta Johanna pa Maks Furijan.

16 Janko Barle, Ipavci: Prilog k zgodovini slovenske pesmi (Ljubljana, 1909 (»Ponatisk iz Doma in sveta«)), 12-13 ; prim. Igor Grdina, Ipavci: Zgodovina slovenske meščanske dinastije (Ljubljana: Založba ZRC, ZRC SAZU, 2001), 42-43.

${ }^{17}$ Barle, Ipavci, 13.

${ }^{18}$ Barle, Ipavci, 8. - Po Barletu naj bi graščak Gadolla, »star, bolehen gospod«, vzel Ipavca s seboj na Dunaj, ko naj bi bil tja poklican k večtedenskemu zborovanju gosposke zbornice. Zbornica tedaj, v drugem desetletju 19. stoletja, v resnici sploh še ni obstajala (prim. datiranje potovanja na Dunaj pred letom 1819 v: Grdina, Ipavci, 44) in potovanje, ki naj bi Ipavcu z Gadollovo 
Ni pa potrjeno tesnejše razmerje med njunima družinama, saj bi se »pokroviteljsko prijateljstvo« blagovenske gospode do Ipavcev - tako je prikazano v televizijski nadaljevanki Ipavci ${ }^{19}$ - prav gotovo odrazilo v botrovanju Ipavčevim krščencem. ${ }^{20}$ Znano je le, da je Katarina Ipavec pogosto hodila na obisk na Blagovno in jemala s seboj svojo najstarejšo hčerko Jeanette (1817-1911). ${ }^{21}$ Blagovenska graščakinja, Valvasorjeva potomka Barbara pl. Gadolla, in njena dva otroka bi sicer težko postali osebni prijatelji Ipavčeve družine, ne le zato, ker niso pripadali istemu stanu, ampak zlasti ob dejstvu, da sta bila Gadollova hči Viljemina in sin Franc skoraj célo generacijo starejša celo od najstarejših Ipavčevih otrok. Najmlajša Benjamin (1829-1908) in Gustav Ipavec (1831-1908) sta bila sploh še najstnika, ko sta leta 1844 tedaj že skoraj petdesetletna Franc vitez Gadolla in njegova sestra Viljemina Blagovno prodala. ${ }^{22}$ Scena iz televizijske nadaljevanke Ipavci, posneta na Šeneku pri Polzeli, ki prikazuje obisk Ipavčeve družine na Blagovni poznega leta 1858 tedaj naj bi jim Gadolla oznanil, da je graščino prodal - je pač plod umetniške svobode. ${ }^{23}$

Več kot le nekaj vrstic - te običajno omenjajo Gadolle samo kot zemljiške gospode - je v slovenskem zgodovinopisju tej družini namenil Igor Grdina. Toda priložnost, da bi o njej izvedeli kaj več, je bila zamujena, ko je Grdina pred desetletjem objavil svoj doktorat o skladateljih Ipavcih in poljudni pregled preteklosti Šentjurja. V zvezi z Gadollovimi se je namreč v obeh zadovoljil skoraj izključno z zapisanim izročilom ter pri tem navedel več faktografskih in interpretativnih netočnosti, na trenutke pa je šel že čez mejo dobrega okusa. ${ }^{24}$ Tako smo družino Gadolla do nedavna poznali zelo površno

pomočjo prineslo »poseben tečaj iz oftalmologije« pri znamenitem prof. G. J. Beeru, je moralo biti povezano z nekimi drugimi opravki Johanna Gadolle v prestolnici (o tem dogodku gl. Barle, Ipavci, 8-9; Eman Pertl, »Ipavci kot zdravniki,« v: Ob odkritju spomenikov skladateljem Ipavcem, ur. Janko Liška in Marjan Žagar (Šentjur pri Celju: Sklad za postavitev spomenikov skladateljem Ipavcem, 1972), 24-26; prim. Grdina, Ipavci, 44-46). Gadolla je bil npr. leta 1806 na Dunaju odposlanec Štajerske pri c. kr. dvorni deputaciji za unovčenje in poravnavo $(k . k$. Einlösungs- und Tilgungs-Hofdeputation) (StLA, Handschriften, Gruppe 2, Hss. 803, fol. 24), na Dunaj pa je potrjeno potoval tudi leta 1810 (Erzherzog Johanns Tagebuchaufzeichnungen von seinem Aufenthalte im Kurorte Rohitsch=Sauerbrunn und über seine Reisen in Untersteiermark aus den Jahren 1810, 1811 und 1812, ur. Anton Schlossar (Gradec: Leykam, 1912), 30).

${ }^{19}$ Gl. op. 15.

${ }^{20}$ Ipavčevih osem otrok, rojenih med letoma 1815 in 1831, je imelo za botre tržanske sosede (Nadškofijski arhiv Maribor (= NŠAM), Matične knjige, Šentjur pri Celju, R 1806-1836, fol. 87, 109, 160, 190, 208, 245, 308, 360). O botrovanjih prim. tudi Grdina, Ipavci, 52.

${ }^{21}$ H. Kartin, Župnija Šentjur pri Celju (tipkopis v župnijskem uradu Šentjur pri Celju), 16. Za kopijo tipkopisa iz župnijskega arhiva se iskreno zahvaljujem kolegu Jožetu Rataju.

${ }^{22}$ Golec, »Pozabljeni 'mali štajerski Valvasor',« 38.

${ }^{23}$ Gl. op. 15.

${ }^{24}$ Grdina, Ipavci; Igor Grdina, Šentjur, Šentjur v času, čas v Šentjurju (Šentjur: Krajevna skupnost, 2002). - Netočna sta npr. oba datuma in letnici rojstva zakoncev Johanna in Barbare Gadolla, glede Gadollovega viteškega stanu, ki bi ga bilo mogoče zelo hitro preveriti, pa se je Grdina zatekel k ugibanju: »Poraja se občutek, da je mož viteški naslov pravzaprav uzurpiral« (Grdina, Ipavci, 34). Dejstvo, da se leta 1799, ko je bilo Johannu Gadolli 42 let, omenja na Blagovni zakupnik gospostva, »bi pričalo o tem, « - tako Grdina (prav tam, 42) - »da je bil mož v resnici bolan in nesposoben za polnokrvnega fevdalca, ki neusmiljeno izžema svoje podložnike«. Podatek, da je 18 let pred smrtjo, pri 56-ih (v resnici 57-ih), napisal svojo prvo znano oporoko, pa Grdina že kar 
in skoraj samo zaradi Ipavcev, ne da bi vedeli za razvejano znanstveno dejavnost očeta Johanna in sina Franca. Valvasorjev praprapravnuk Franc vitez Gadolla, »mali štajerski Valvasor«, je na svoj obsežni domoznanski opus, ki je ostal v rokopisu in pristal v Štajerskem deželnem arhivu v Gradcu, opozoril šele na prelomu iz 20. v 21. stoletje, in sicer po zaslugi svojega pravnuka, polkovnika Egona Ehrlicha (1931, Gradec). Desetletje po odkritju pradedovega opusa se mi je Ehrlich v začetku leta 2007 preko svetovnega spleta nehote razkril kot prvi živeči potomec Janeza Vajkarda Valvasorja, pri čemer za slavnega prednika dotlej še nikoli ni slišal. Ugotovitev ne preseneča, kajti na Valvasorja je njegovo štajersko potomstvo nasploh hitro pozabilo. In čeprav je Franc Gadolla (1797, Blagovna - 1866, Gradec) kot ljubiteljski zgodovinar med drugim raziskoval tudi svoj rod, nikakor ni mogel dognati, kateri od Valvasorjev je bil oče njegove praprababice Regine Konstancije, poročene Dienersperg. Janeza Vajkarda je sicer visoko cenil, ga imenoval celo »kranjski Livij« in bil zase prepričan, da je ljubezen do »domovinske zgodovine« podedoval prav po Valvasorjevem rodu. Več kot poldrugo stoletje po smrti Franca viteza Gadolle, ko se je pokazalo, da je bil kranjski polihistor njegov neposredni prednik v šesti generaciji, so blagovenski Gadollovi prav zaradi sorodstva z Valvasorjem postali za slovensko zgodovinsko in kulturno javnost še zanimivejši ${ }^{25}$

Njihova graščina Blagovna pri Šentjurju je bila, kot jo je pozneje označil Franc Gadolla, »bivališče muz« in »domovanje znanosti«, sicer pa naj bi glede na velikost, lepe stavbe in vrtove sodila med najlepše na Štajerskem. V času gospodarjenja očeta Johanna (od 1783 do 1832) se je lahko pohvalila, da nudi streho dragoceni in veliki knjižici z deli naravoslovne vsebine, bogatim zbirkam in številnim napravam za raziskovalne poskuse. Sin Franc pa se za razliko od očeta ni toliko ukvarjal z naravoslovjem, temveč predvsem z domoznanstvom in zgodovino. ${ }^{26}$ Da je bila Blagovna resnično nekaj posebnega, potrjujejo besede nadvojvode Janeza (Johanna) Habsburškega (1782-1859), brata cesarja Franca I., ki je ob obiskih pri Godollovih v letih 1810 do 1812 neizmerno užival v družbi gostiteljev in povabljenih, obdan z »dobrimi Štajerci«. Poleg omemb lepe knjižnice, čednih zbirk in živalskega vrta je $\mathrm{v}$ dnevniških zapiskih tega samosvojega Habsburžana najti tudi najzgodnejši podatek o tem, da je imela v Gadollovi hiši svoje mesto glasba. Po prvem obisku na Blagovni poleti 1810 je nadvojvoda Janez poleg nadvse izčrpnega opisa okolice »tega sicer starega, a dobro zgrajenega in udobnega gradu $\ll,{ }^{27}$ zapisal naslednje besede:

»Gospostvo pripada gospodu Gadolli, pametnemu, razgledanemu možu, do vseh

cinično razlaga kot: »Gadolla je očitno kar naprej umiral, pokopati pa dolgo ni bilo ničesar« (prav tam). Ko bi dal komu prebrati samo prvi stavek oporoke, ki jo v opombi citira, si česa takega ne bi mogel privoščiti; Gadolla govori namreč zgolj o možnosti nenadne smrti, kar je pri njegovih letih nekaj povsem normalnega (ZAC, ZAC/0495, Krajevno sodišče gospoščine Blagovna, šk. 2, Gadolla, 1. 3. 1814). Brez racionalne podlage je tudi Grdinova trditev, da se je grad Turn pri Škalah zdel Francu Gadolli »v vsakem primeru imenitnejši in se je zato preselil tja« (Grdina, Ipavci, 85). Markantna Blagovna pri Šentjurju, mimo katerega je že dve leti po Gadollovi prodaji Blagovne (1846) prisopihal vlak, je ležala tik od deželni cesti proti Hrvaški in bi v resnici še naprej ostala Gadollova, ko bi to le bilo mogoče (Golec, »Pozabljeni 'mali štajerski Valvasor',« $35-38)$.

${ }^{25}$ Gl. zlasti Golec, »Pozabljeni 'mali štajerski Valvasor'.«

${ }^{26}$ Prav tam, 33-35.

${ }^{27}$ Schlossar, Erzherzog Johanns, 26-28. 


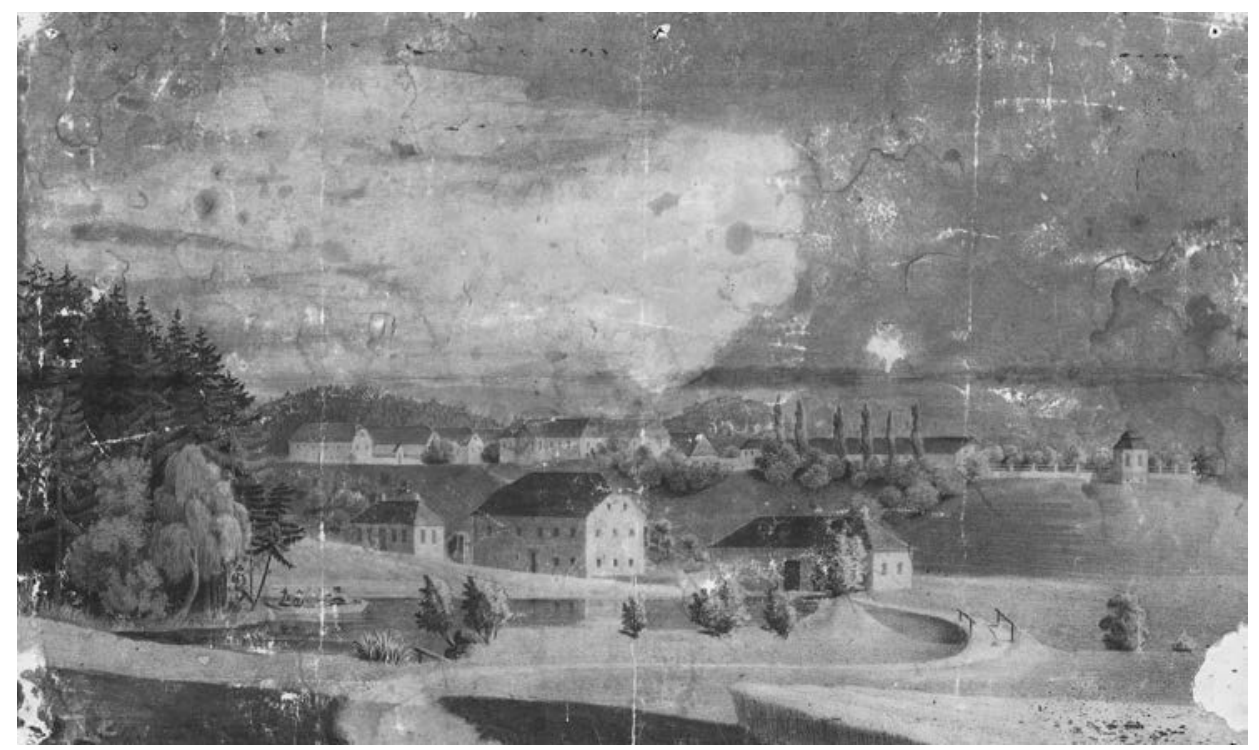

Zadnja upodobitev Blagovne leta 1858, preden je dal novi lastnik graščino porušiti: v ospredju nekdanja kmetija Suša, v ozadju na levi graščinska gospodarska poslopja in še obstoječa upravna stavba, desno enonadstropni graščinski kompleks (ARS, AS 455, Zbirka likovnih del, št. 62, avtor M. Doberšek).

gostoljubnemu; ima lepo knjižnico in nekaj čednih zbirk, svojo okolico pozna izvrstno. Dan sem preživel izjemno dobre volje, okrožni glavar iz Celja baron Juritsch je prišel tja s svojo ženo in svakinjo, družbo pa so zaokroževali še lastnik, njegova žena in hči. Šli smo na sprehod, jedli na prostem, nobenega sledu o vsej tisti dunajski prisiljenosti. Zvečer je bil vrt razsvetljen in jedli smo v vrtni hiši ob spremljavi glasbe [»unter Begleitung einer Musik«], veliko lepšo pa je izvabila čudovita nevihta, ta je ponehala po močnem nalivu, ki je ugasnil svetilke. Zatem smo šli vsi spat. (28 $^{28}$

Tehnično usmerjeni nadvojvoda ni izpričal, kakšne vrste glasba je spremljala večerjo. Nad njo očitno ni bil ravno vzhičen, a glede na to, da ni omenil plesa, bi glasbena spremljava vendarle utegnila biti več kot le godčevsko muziciranje - drugače kot npr. naslednje leto na obisku v župnišču v Novi Cerkvi, kjer se je nadvojvoda mudil skupaj z zakoncema Gadolla in se do jutra vrtel v ritmu štajriša (»obersteirisch «). ${ }^{29}$ Poleg tega gre opozoriti, da leta 1810 na Blagovni še ni živela mati skladateljev Ipavcev, ki jo poznamo kot izvrstno instrumentalistko. ${ }^{30}$

Kakor koli, glasba je bila na Blagovni očitno redna spremljevalka družabnega življenja, vendar moški del Gadollove družine, oče Johann in sin Franc, po vsem sodeč nista bila več kot njena pasivna podpornika in častilca, o morebitnem glasbenem talentu

\footnotetext{
${ }^{28}$ Prav tam, 28.

${ }^{29}$ Prav tam, 89.

${ }^{30}$ Prim. Barle, Ipavci, 12-13; prim. Grdina, Ipavci, 42-43.
} 
matere Barbare in hčerke Viljemine pa viri molčijo. Ko se je Franc Gadolla v poznejših letih na široko razpisal o tem, kakšna knjižna dela je bilo najti v (očetovi) blagovenski knjižnici, se ustavil ob zbirkah kamnin in novcev ter posebej ob raznovrstnih tehničnih napravah, ni našel besed za »lepe umetnosti « ${ }^{31}$ - tako kot ni opisoval še marsičesa, s čimer se je ukvarjal, ampak najdemo o teh dejavnostih le bežne omembe in niti ne vse izpod njegovega peresa. ${ }^{32}$ Ena takih obrobnih omemb je za našo problematiko še posebej pomenljiva. V nekem svojem rokopisu iz leta 1836 je Gadolla o sebi izpričal, da je končal pravni študij na »terezijanski viteški akademiji« na Dunaju, omenil svojo že zaključeno uradniško kariero pri celjskem okrožnem uradu, se naslovil kot lastnik gospostev, deželan, član Kmetijske družbe za Štajersko in končno - kot častni član Glasbenega društva v Celju (»Ehrenmitglied des Musikvereins zu Cilli«). ${ }^{33} \mathrm{O}$ tej njegovi vlogi ni znanega nič določenega, tako kot vemo zelo malo o društvu samem.

Odkritje obsežnega domoznanskega opusa Franca viteza Gadolle, shranjenega v Štajerskem deželnem arhivu v Gradcu, ni sicer prineslo nobenih novih podatkov o rodbini Ipavec niti o glasbenem poustvarjanju na Gadollovi rodni Blagovni, kar je tudi razumljivo. 56 rokopisov na okoli 3.300 straneh, napisanih po večini po letu 1845 na Gadollovem novem domu, graščini Turn pri Škalah, je namreč skoraj v celoti posvečeno zgodovini in topografiji. Franc Gadolla jih je kot član Historičnega društva za Štajersko ter društveni korespondent za Savinjsko dolino in okolico (oboje od 1854) pisal za društveni arhiv in načrtoval objavo vsaj dela svojega opusa, za kar mu je nazadnje zmanjkalo časa. ${ }^{34}$

Glede na naravo Gadollovih rokopisov ne izvemo tako iz prve roke skoraj nič o njegovem družinskem življenju. ${ }^{35}$ Potem ko se je pri 47-ih jeseni 1844 na Dunaju oženil z 29 let mlajšo Kajetano baronico Adelstein (1826, Videm/Udine - 1912, Gradec) - po očetovi strani z Dobrnice pri Dobrni, po materini pa z Goriškega -, se je zakoncema na Turnu pri Škalah rodilo šest otrok (1846-1861). Leta 1862, štiri leta pred svojo smrtjo, pa je Gadolla Turn prodal in se z družino preselil v Gradec. ${ }^{36} \mathrm{~K}$ sreči se je iz njegovega turnskega in graškega obdobja ohranil del korespondence, ki skupaj z zapuščinskim inventarjem (1866) razkriva tudi nekaj dragocenih drobcev o glasbenem poustvarjanju v družini. Tako kot pri Dienerspergih je skoraj vse védenje omejeno na instrument klavir in na ženski del družine. Potem ko se je Gadolla leta 1854 seznanil z generacijo mlajšim duhovnikom in zgodovinarjem Ignacem Orožnom (1819-1900), je Orožen, takrat župnik v Mozirju, v pismu Gadolli z dne 16. oktobra 1855 med drugim napisal tudi te

${ }^{31}$ StLA, Handschriften, Gruppe 2, Hss. 678, fol. 23'-24. - Gadolla ni imel posebnega umetniškega čuta. V nasprotnem primeru se v svojih rokopisih ne bi tako izogibal umetnosti, o blagovenskih »umetniških kabinetih« (»Kunst Cabinette«) pa leta 1864 ne bi zapisal, da takih reči »noče kupiti noben hudič« (prav tam, Hss. 908, fol. 19').

${ }^{32}$ Tako npr. iz spominov Gadollovega sina Klemensa (1847-1919) izvemo, da se je oče ukvarjal $\mathrm{s} »$ fizikalnimi poskusi«, njegov »fizikalni kabinet«, ki ga je imel še leta $1865 \mathrm{v}$ Gradcu, pa je omenjen samo v pismu nekega Huberja iz Celja (Golec, »Pozabljeni 'mali štajerski Valvasor',« $39,41)$.

${ }^{33}$ StLA, Handschriften, Gruppe 2, Hss. 803, fol. 24.

${ }^{34}$ Golec, »Pozabljeni 'mali štajerski Valvasor',« 44-48.

${ }^{35} \mathrm{O}$ družinskem življenju Gadollovih je v svojih spominih še največ napisal Frančev najstarejši sin Klemens (1847-1919), vendar samo za obdobje, ki ga je doživel sam (prav tam, 39).

${ }^{36}$ Golec, »Pozabljeni 'mali štajerski Valvasor',« 39. 
besede: »Na pisanje Vašega blagorodja z dne 14. t. m. hitim odgovarjati, da tu v Mozirju ne zmoremo izpolniti Vaše želje glede uglaševalca klavirja, kajti nobeden od naših dveh učiteljev ni dober igralec klavirja, še manj pa se spoznata na uglaševanje. Kadar hočem dati uglasiti svoj klavir, moram vedno poslati po pomočnika izdelovalca orgel Hörbigerja s Štravseneka, ki pa ga ni lahko dobiti.« ${ }^{37}$ Skoraj gotovo je isti klavir omenjen tudi enajst let pozneje (1866) v Gadollovem zapuščinskem inventarju, sestavljenem v Gradcu slab mesec po njegovi smrti. Izvedeti je mogoče, da je 150 goldinarjev vredni instrument pripadal Gadollovi najstarejši hčerki Josefine kot darilo njene stare matere, ${ }^{38}$ torej materine matere Klementine baronice Adelstein, rojene grofice Coronini (1792-1867). ${ }^{39}$ Josefine (1846-1889) najverjetneje ni šla po poti svoje devet let mlajše mrzle sestrične Antonije baronice Dienersperg, ki je končala dunajski konservatorij, ampak je igranje klavirja predstavljalo samo del njene damske vzgoje. Spomini njenega brata Klemensa, s katero jo je vezalo vseživljenjsko prijateljstvo, namreč ne govorijo o sestrinem glasbenem šolanju. Podobno kot Josefine sta se prejkone učili klavirja tudi njeni dve mlajši sestri Johanna in Elise, ki sta obe postali učiteljici in se poročili s stanovskima kolegoma neplemiškega rodu. Josefine je nasprotno ostala neomožena, postala »c. kr. dama« graške ženske plemiške ustanove (»k. k. Stiftsdame«) in umrla stara komaj 43 let med zdravljenjem v zdravilišču Dobrna, nekoč v lasti njenih prednikov baronov Dienerspergov. ${ }^{40}$

Tudi pri poznejših generacijah Gadollove rodbine ne najdemo nikogar posebno nadarjenega za glasbo. Obubožana plemiška družina, ki se je po prodaji Turna znašla v Gradcu brez rednega vira dohodkov in ki ji je kupnina za graščino precej hitro izpuhtela, je morala v prvi vrsti poskrbeti za eksistenco. Veliko moških članov Gadollovega rodu je tako vse do devetdesetih let 20. stoletja polnilo častniške vrste različnih vojsk in ta veja Valvasorjevega potomstva je na oltarje svojih domovin položila preštevilne človeške žrtve. ${ }^{41}$ Rezervni častnik in invalid iz prve svetovne vojne je bil tudi zadnji Valvasorjev na Slovenskem živeči potomec, železniški uradnik Karl Mayer (1890-1941). Ta nesrečni mariborski Nemec, vnuk Franca Gadolle, je kot psihični bolnik in dolgoletni varovanec umobolnice v Novem Celju postal žrtev nacistične evtanazije. Posebej kaže omeniti, da je poleg strasti do pisanja kazal izrazito zanimanje za gledališče in koncerte, o čemer priča njegova neoddana korespondenca, napisana v letih 1924 in 1925 v ljubljanski umobolnici na Studencu. ${ }^{42}$ Med pismi je tudi eno, naslovljeno v Maribor ginekologu dr. Karlu Ipavcu (1878-1962), Gustavovemu sinu, sicer prav tako velikemu ljubitelju gledališča. ${ }^{43}$ Komaj

${ }^{37}$ StLA, Handschriften, Gruppe 2, Hss. 919, pismo I. Orožna, 16. 10. 1854.

${ }^{38}$ StLA, Bezirksgericht Graz I, D 117/1867, No. 3, 18. 5. 1866.

${ }^{39}$ O Adelsteinih gl. Johann Baptist Witting, Steiermärkischer Adel (Nürnberg, 1919-1921). Ponatis: Die Wappen des Adels in Salzburg, Steiermark und Tirol, zv. 1, Siebmacher's großes Wappenbuch 28 (Neustadt an der Aisch: Bauer \& Raspe, 1979), 5.

${ }^{40}$ Golec, »Pozabljeni 'mali štajerski Valvasor',« 69-70; Golec, »Valvasorjevo neznano potomstvo« (3. del), 61.

${ }^{41}$ Boris Golec, »Vojaška in častniška komponenta pri potomcih polihistorja Janeza Vajkarda Valvasorja (1641-1693) do danes: Zgodba neke razvejane slovensko-avstrijske plemiške rodbine,« v: Vojaki iz slovenskega prostora na tujih tleh v preteklosti, ur. Darja Mihelič in Matjaž Bizjak (Ljubljana: Založba ZRC, Zgodovinski inštitut Milka Kosa ZRC SAZU, 2011), 226-228, 231-241.

${ }^{42}$ Golec, »'Der Hudič ist hier zu Hause',« 72-92.

${ }^{43}$ Mayer je pisal dr. Ipavcu kot neke vrste zaupniku, ga prosil za nekaj priboljškov, ki naj bi jih 
bi verjeli, da je bilo njuno znanstvo nadaljevanje kakšne stare družinske povezanosti med Ipavci in Gadollami, saj je tedaj minilo že osemdeset let, odkar so Gadollovi zapustili Blagovno pri Šentjurju.

Gadollova veja Valvasorjevega potomstva je bila torej veliko bolj ljubiteljica in spremljevalka glasbe kakor njena poustvarjalka, a ima v slovenski kulturni zavesti posebno mesto zaradi povezanosti z družino Ipavec. Tako je Franc Gadolla edini potomec kranjskega polihistorja, čigar lik je ovekovečen v igrani televizijski upodobitvi. ${ }^{44}$

\section{Resingenova rodbinska veja - od čitalniških samospevov do skladatelja Rudolfa von Weis-Ostborna}

Iz tretje, Resingenove veje Valvasorjevega rodu, katere začetnica je bila Terezija baronica Dienersperg, por. pl. Resingen (1776, Dobrna - 1849, Gradec), je izšla edina glasbena osebnost med polihistorjevim potomstvom, štajerski skladatelj Rudolf von Weis-Ostborn (1876-1962, Gradec). Gre za Terezijinega prapravnuka, ki ga slovenska glasbena in kulturna zgodovina sicer pozna kot predzadnjega direktorja nemško usmerjene Filharmonične družbe v Ljubljani in o katerem bo tekla beseda pozneje. Ni dvoma, da je nagnjenje do glasbe podedoval predvsem po očetovi strani, saj sta bila glasbenika tako njegov oče kot ded, toda družinsko izročilo je ljubezen do glasbe izpričalo tudi v materini družini, pri potomstvu kranjskega polihistorja. Rudolfov nečak dr. Bruno Brandstetter (1894-1993, Gradec) je v tipkopisu o gradovih svojega sorodstva (1988), napisanem pri častitljivih 95-ih letih, po spominu zapisal naslednje pomenljive besede, ki jih je večkrat slišal od svoje babice, Rudolfove matere:

»Moja stara mati Angela Weis von Ostborn, roj. Sterger (1844-1921), mi je pogosto pripovedovala, kako je bila kot mlado dekle prva, ki je na nekem javnem koncertu v Ljubljani pela slovenske pesmi (nekega dr. Ipawitza, zdravnika), ko je slovensko govorila samo služinčad. Njen sin Rudolf(1876-1962) je bil med prvo svetovno vojno (1914-1918) dirigent ljubljanske filharmonije in direktor glasbene akademije. Leta 1918 je nastala jugoslovanska država Slovenija in nemško govoreči prebivalci so morali deželo zapustiti.« «5

Brez tega skromnega zapisa bi bili prikrajšani za dragoceno védenje o glasbenem poustvarjanju v Resingenovi veji Valvasorjevega sorodstva, preden je iz nje izšel skladatelj von Weis-Ostborn. Brandstetterjeve besede, zapisane več kot 120 let po nastopu njegove stare matere Angele Sterger v Ljubljani, so se namreč potrdile kot resnične. V Bleiweisovih Novicah najdemo obširno poročilo o dobrodelni velikonočni bésedi, ki so

Ipavec kupil z njegovim denarjem, in za posredovanje pri mariborskem magistratu (Arhiv Psihiatrične klinike Ljubljana, G-4177, Mayer Karol, 13. 10. 1924). - O Karlu Ipavcu: Grdina, Ipavci, 311-312.

${ }^{44}$ Gl. op. 15.

${ }^{45}$ Bruno Brandstetter, Burgen und Schlösser meiner Vorfahren in mütterlicher Linie und deren Verwandten in Steiermark, Kärnten und Krain. Chronik einer Grossfamilie (Gradec, 1988, rokopis), 200. - Avtor je kot letnico Rudolfove smrti pomotoma navedel leto 1964, pri »državi Sloveniji« pa gre bržkone za prepisovalsko napako. Beseda »Slowenien« se je prikradla za »der jugoslawische Staat«, morala pa bi slediti besedi »Land«: »das Land Slowenien verlassen«. 
jo priredili 17. aprila 1865 v ljubljanskem deželnem gledališču. Takole je o dogodku v gledališču pisal novičar: ${ }^{46}$

»Razdeljena je bila zdaj beseda v tri oddelke. [...] Prvi razdelek je bil muzikalni. Poveličale ste ta del prekrasni gospodičini Angela in Gabriela, ki ste s svojim očetom, visokospoštovanim našim rojakom, gosp. dr. Stergerjem iz Gradca nalašč prišle v Ljubljano, da ste gledé na milodarni namen se udeležile naše besede. Oj! kako ste pele - Angela s svojim preljubeznjivim mezzo-sopranom in Gabriela s svojim briljantnim sopranom! Ako je una srca topila s Ipavčevo "Lahko noč" in "Ostani pri meni", je ta radostna čutja izbujevala v Strakošovi "D' amore giubilo" - obé pa v Mozartovem dvospevu "Nozze di Figaro" zibale poslušavce v rajskem veselji. Da se je ob odpetih pesmah gledišče vselej ploska treslo, ni nam treba še posebej omenjati.« Nekaj odstavkov naprej piše isto časnikarsko pero še o družabnem nadaljevanju večera: »Po gledišču je bila vesela večerja v čitavnici, ktera ni ostala brez navdušenih napitnic. Dr. Orel je napil vrlemu gosp. dr. Stergerju, dr. Bleiweis vsem pomočnicam in pomočnikom današnje slovesne besede, dr. Lavrič iz Ajdovščine krasnemu spolu slovenskemu, dr. Nabergoj iz Proseka čitavnici in sokolu. Pred odhodom v Trst ste nas še v čitavnici razveseljevale ljubeznivi gospodičini Stergerjevi z nepozabnim svojim petjem. Živili! « ${ }^{47}$

Poleg tedaj 21-letne Angele Sterger, matere skladatelja Rudolfa von Weis-Ostborna, je kot pevka torej nastopila tudi njena leto dni starejša sestra Gabrielle (1843-1914, Gradec), pozneje poročena baronica Rokitansky. Obe sta pripotovali v Ljubljano iz rodnega Gradca skupaj z očetom, odvetnikom dr. Francem Stergerjem (1807-1888), kranjskim rojakom, rojenim v graščinici Brest na Ljubljanskem barju. ${ }^{48}$ Vnuk dr. Bruno Brandstetter si je vsekakor zelo dobro zapomnil pripoved svoje babice o njenem odmevnem nastopu v kranjski prestolnici in je vrhu tega pomnil tudi priimek in poklic skladatelja (»von dr. Ipawitz, einem Arzte«). V mislih bi lahko imel katerega koli od treh bratov Ipavec, saj so bili vsi zdravniki, a najbrž ni vedel več kot za njihov priimek. Samospev Lahko noč, omenjen v časopisnem poročilu, je Gustavov, toda Angela je po koncertu najbrž zapela še kaj Ipavčevega. Več kot verjetno je, da je družina odvetnika Stergerja osebno poznala graškega otroškega zdravnika in skladatelja dr. Benjamina Ipavca, če ne tudi Gustava, zdravnika v rodnem Šentjurju, saj sta se oba šolala v Gradcu. ${ }^{49}$

Časopisno poročilo o koncertu leta 1865 ne omenja Stergerjeve žene Terezije, rojene

$46 »$ Iz Ljubljane, « Novice gospodarske, obrtniške in narodne 23, št. 16 (19. 4. 1865): 132. - Časopisno notico o nastopu sester Sterger je poiskala dr. Nataša Cigoj Krstulović, za kar se ji iskreno zahvaljujem.

47 Omenjene osebe so bili sami vidni narodni delavci: dr. Jožef Orel (1797-1874), dr. Janez Bleiweis (1808-1881), dr. Karel Lavrič (1818-1876) in dr. Ivan Nabergoj (1835-1902).

${ }^{48}$ O Stergerju: Golec, »Valvasorjevo neznano potomstvo« (2. del), 359-360; Boris Golec, »Poti in stranpoti Valvasorjevih potomcev z velenjskega gradu: Kdaj arhivski viri (ne) lažejo?,« Arhivi 34 (2011): 513-516.

49 Janko Barle, »Ipavec, Benjamin,« v: Slovenski biografski leksikon, zv. 1, ur. Izidor Cankar in Franc Ksaver Lukman (Ljubljana: Zadružna gospodarska banka, 1925-1932), 363-364; Janko Barle, »Ipavec, Gustav, « v: Slovenski biografski leksikon, zv. 1, ur. Izidor Cankar in Franc Ksaver Lukman (Ljubljana: Zadružna gospodarska banka, 1925-1932), 364-365. - Omeniti kaže, da je poznejši soprog Stergerjeve vnukinje Emanuele von Weis-Ostborn (1870-1930), znani štajerski akademski kipar in profesor Hans Brandstetter (1854-1925), leta 1887 obiskal družino Gustava 
Pauer (1826-1869), stare matere skladatelja von Weis-Ostborna, ki svojega moža in hčerk tedaj očitno ni spremljala v Ljubljano in Trst. Ta nesrečna dama, Valvasorjeva pravnukinja $\mathrm{v}$ četrtem kolenu, je bila prav tako kot njen mož rojena na Slovenskem, in sicer na gradu Velenje, ki ga je njen oče izgubil, ko je bilo Tereziji tri leta. Odraščala je v Celju in na domu svojih starih staršev, v Resingenovi graščini Tabor pri Vojniku, po materini vnovični možitvi (1841) pa se je z očimom, materjo in tremi brati preselila v Gradec, kjer se je komaj 16-letna že naslednjega leta 1842 omožila z 19 let starejšim odvetnikom dr. Stergerjem in imela z njim štiri hčerke. Po dobrega četrt stoletja ponesrečenega zakona je zaradi moževe nezvestobe na družinski posesti pri Sv. Ani (Veliki Vrh) v Halozah naredila samomor, stara 43 let. »Sramotno dejanje« je njena družina javnosti bolj ali manj spretno prikrivala, tako da za pravi vzrok smrti ne bi vedeli, ko ga leta 1988 ne bi v že znani »družinski kroniki« omenil Terezijin pravnuk dr. Bruno Brandstetter. ${ }^{50}$

Dne 9. februarja 1869, le slaba dva meseca pred Terezijino smrtjo, se je njena hči Angela, poznejša mati skladatelja Rudolfa, v rodnem Gradcu omožila z doktorandom prava Johannom Weisom, Dunajčanom, ki je s starši živel v štajerski prestolnici in tedaj še ni imel plemiškega naslova. Glede na rojstvo njunega prvega otroka komaj dva meseca po poroki, 9. aprila na potovanju v Benetkah in prav na dan pogreba Angeline matere, sklenitev tega zakona ni potekala po družbenih normah. Zveza med 25-letno Angelo in njenim poldrugo leto mlajšim izvoljencem Johannom (1846, Dunaj - 1906, Weiz), poznejšim odvetnikom, najverjetneje zato ni dobila (takojšnjega) blagoslova njunih družin, ker Weis še ni končal študija. Nobenega dvoma pa ni, da ji je botrovala skupna ljubezen do glasbe. ${ }^{51}$ Johann (Hans) je bil namreč sin priznanega violinista Josefa Weisa, dopisoval si je z Richardom Wagnerjem in je še zelo mlad, prav v letu svoje poroke, zložil opereto Der Sonntagsjäger. ${ }^{52}$

Zakoncema Weis so se v zakonu rodili štirje otroci, od katerih je tretjerojeni Rudolf, rojen 8 . novembra 1876, prišel na svet kot prvi s plemiškim naslovom »Ritter von Ostborn «. Tega je zase in za potomce dobil leta 1872 njegov ded Josef Weis (1806-1904), omenjeni violinist, sicer direktor okrajnega finančnega urada in nekdanji častnik. ${ }^{53}$ Takšno popotnico je torej prinesel na svet poznejši skladatelj, ki bi ga lahko imenovali tudi mož s tremi priimki oziroma različicami priimka. Rojen kot »Weis Ritter von Ostborn« je do svojih zrelih let uporabljal različico »von Weis-Ostborn«, običajno pri vseh družinskih članih. Ko pa je prva avstrijska republika 3. aprila 1919 plemiške naslove odpravila, mu je štajerska deželna vlada 31. oktobra 1920 dovolila spremembo priimka v »Weis-Ostborn «. ${ }^{54}$

Ipavca v Šentjurju (Grdina, Ipavci, 186). O Brandstetterju Golec, »Valvasorjevo neznano potomstvo« (2. del), 363.

${ }^{50}$ Golec, »Poti in stranpoti, « 501-504, 513-516.

${ }^{51}$ Golec, »Valvasorjevo neznano potomstvo« (2. del), 361-362.

${ }^{52}$ Österreichisches Musiklexikon, zv. 5, ur. Rudolf Flotzinger (Dunaj: Verlag der Österreichischen Akademie der Wissenschaften, 2006), 2615.

${ }^{53}$ Peter Frank-Döfering, Adelslexikon des Österreichischen Kaisertums 1804-1918 (Dunaj: Herder \& Co., 1989), 558, št. 10088. - O Josefu Weis(-Ostbornu): Österreichisches Musiklexikon, zv. 5, 2615.

${ }^{54} \mathrm{O}$ tem zaznamek pri vpisu njegovega rojstva v rojstni matični knjigi (Diözesanarchiv Graz-Seckau (= DAG), Altmatriken, Graz-St. Andrä, Taufbuch XI 1876-1880, str. 490). 
O Rudolfovem življenju bi lahko rekli, da je šlo za življenjsko pot precej »konvencionalnega umetnika«. Od Valvasorjevih potomcev se je edini vpisal v regionalno zgodovino, natančneje rečeno v zgodovino glasbenega ustvarjanja in poustvarjanja na avstrijskem Štajerskem in deloma tudi na nekdanjem Kranjskem. Zapustil je ustvarjalni opus in si v rodnem Gradcu prislužil dve spominski znamenji: relief v prvem nadstropju Deželne glasbene šole ter spominsko ploščo na hiši tik ob graški stolnici, v kateri je preživel zadnja štiri desetletja svojega življenja do smrti 18. novembra $1962 .{ }^{55}$

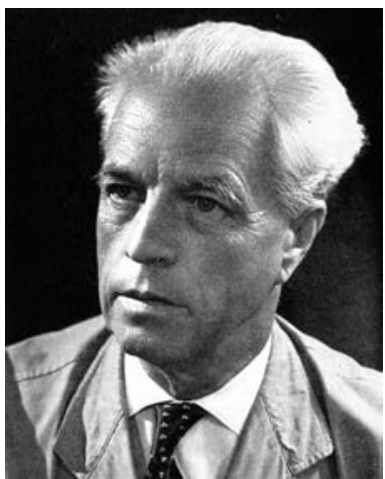

Valvasorjev pravnuk v šestem kolenu, skladatelj Rudolf von Weis-Ostborn (1876-1962)

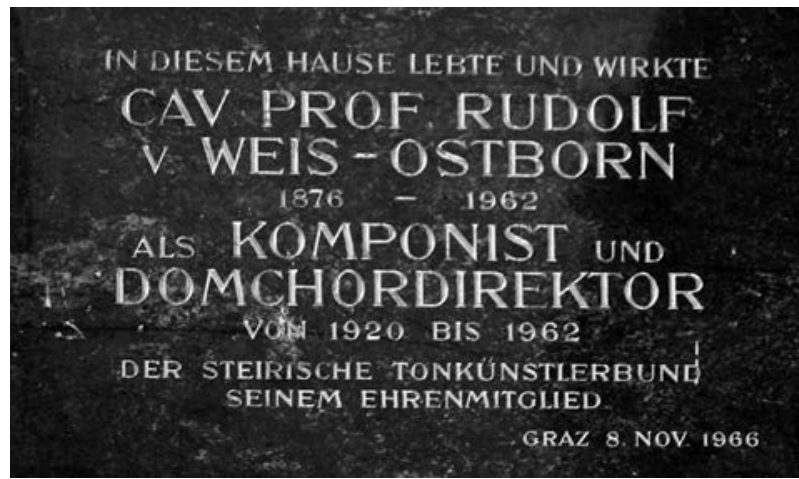

Spominska plošča Rudolfu von Weis-Ostbornu, odkrita leta 1966 na pročelju hiše v Burggasse 5 v Gradcu (foto: B. Golec, junij 2009)

Kot glasbenega poustvarjalca in skladatelja ga dobro pozna štajerska glasbena zgodovina in nekoliko manj širša avstrijska. ${ }^{56}$ Upravičeno ni uvrščen med slovenske skladatelje, nima pa niti vidnejšega mesta med glasbeniki, ki so delovali na Slovenskem, s čimer mu Valvasorjeva domovina vendarle dela krivico. V polihistorjevem rojstnem mestu v svojem času sicer ni igral vloge, ki bi jo slovenska (strokovna) javnost želela pomniti. V Ljubljani je bil uradno dobrih šest let, od leta 1913 do 1919, kot direktor »nemške« Filharmonične družbe (Philharmonische Gesellschaft), in to za povrh v viharnem času okoli prve svetovne vojne. Dejansko je na Kranjskem preživel precej manj časa, saj je dobršen del vojnih let nosil uniformo, ko pa je pred koncem vojne vihre končno spet oblekel civilno obleko in si nadel dirigentski frak, mu okoliščine v novorojeni jugoslovanski državi niso bile več naklonjene. Vrnil se je v rodni Gradec in bil v »Valvasorjevi deželi« kljub prejšnjim

${ }^{55}$ Konrad Stek1, »Die Tätigkeit eines steirischen Musikdirektors: Rudolf von Weis-Ostborn, « v: Steirische Musikerjubiläen 1971: Festschrift, ur. Konrad Stek1 in Wolfgang Suppan (Gradec: Akademische Druck- und Verlagsanstalt, 1971), 46. Iz tega dela je vzeta tudi v pričujoči razpravi objavljena fotografija.

${ }^{56}$ Prim. Musik in der Steiermark: Katalog der Landesausstellung 1980, ur. Rudolf Flotzinger (Gradec: Referat der Steiermärkischen Landesregierung, 1980), 386; Österreichisches Musiklexikon, zv. 5, 2615. Slovenski strokovni javnosti je bil prvič predstavljen v delu: Golec, »'Der Hudič ist hier zu Hause',« 61-66. Obravnava R. von Weis-Ostborna je v tem prispevku povzeta po navedeni objavi, le da je nekoliko predelana. 
častem in slavi zelo hitro pozabljen. Iz sna pozabe sta ga šele v zadnjem času v monografijah o glasbenem šolstvu na Slovenskem in ljubljanski Filharmonični družbi obudila C. Budkovič (1995) ${ }^{57}$ in P. Kuret (2005). ${ }^{58}$ Nekaj podatkov o von Weis-Ostbornovem ljubljanskem obdobju so prinesli tudi v slovenščino prevedeni spomini Hansa Gerstnerja, njegovega naslednika na čelu Filharmonične družbe (2010). ${ }^{59}$ Pri vseh pa bomo zaman iskali podatek, da je šlo za potomca znamenitega kranjskega polihistorja iz 17. stoletja.

Najbrž ne bomo nikoli zanesljivo vedeli, ali se je Rudolf von Weis-Ostborn med bivanjem v Ljubljani sploh zavedal, da ga kaj veže $\mathrm{z}$ možem, čigar bronasta podoba $\mathrm{v}$ dvakratni naravni velikosti je od leta 1903 krasila park pred kranjskim deželnim muzejem Rudolfinumom kot eden največjih javnih spomenikov v mestu. A tudi če je svojo sorodstveno zvezo s polihistorjem poznal, temu dejstvu gotovo ni posvečal niti približno tolikšne pozornosti kot svoji prvi ljubezni - glasbi. Da se z Valvasorjem vsaj javno ni ponašal, lahko sklepamo ob dejstvu, da v sodobnih časopisnih poročilih, kot kaže, ni nihče niti z besedico omenil, kaj povezuje novega ravnatelja Filharmonične družbe s Kranjsko. ${ }^{60}$ Morda, a to še zdaleč ni gotovo, je Rudolf za svojo genealoško povezavo s polihistorjem izvedel pozneje, ko se je do takšnih ugotovitev dokopal njegov nečak Friedrich WeisOstborn (1896-1978, Gradec). Po nečakovi zaslugi je védenje o Valvasorju v tej družini ostajalo živo, a do nedavna med večino potomcev ni bilo razširjeno. ${ }^{61}$

Kdo je bil torej štajerski skladatelj Rudolf (von) Weis-Ostborn? ${ }^{62} \mathrm{~V}$ rodnem Gradcu je študiral umetnostno zgodovino, muzikologijo in estetiko ter leta 1900 na tamkajšnji filozofski fakulteti dosegel absolutorij. Med študijem je obiskoval glasbeno šolo Štajerskega glasbenega društva (Steiermärkischer Musikverein) pod vodstvom E. W. Degnerja, izšolal

${ }^{57}$ Cvetko Budkovič, Razvoj glasbenega šolstva na Slovenskem, zv. 1, Od začetka 19. stoletja do nastanka konservatorija (Ljubljana: Znanstveni inštitut Filozofske fakultete, 1992), 118-120, $125,355,356$.

${ }^{58}$ Primož Kuret, Ljubljanska filharmonična družba 1794-1919: Kronika glasbenega življenja v stoletju meščanov in revolucij (Ljubljana: Nova revija, 2005), 235, 366, 397, 399, 404, 409, 411, 412, 414, 417, 420, 439, 442, 445.

59 Jernej Weiss, Hans Gerstner (1851-1939): Življenje za glasbo (Maribor: Litera, Pedagoška fakulteta, 2010), 159-170, 164, 170.

${ }^{60} \mathrm{C}$. Budkovič je po Laibacher Zeitung in razni publicistiki povzel o Weis-Ostbornovem socialnem zaledju samo to, da je bil sin odvetnika in da so v hiši veliko peli in muzicirali (Budkovič, Razvoj glasbenega šolstva, zv. 1, 118, op. 251).

${ }^{61}$ Zanimivo je, da za Valvasorja ni vedela Friedrichova letos (2012) preminula hči, upokojena učiteljica Elfriede Weis-Ostborn, roj. 1921 (telefonski pogovor z avtorjem 2. 4. 2009). Zato pa je Friedrich prenesel védenje o Valvasorju in svoje rodoslovne izsledke na vnuka, dr. Franza Mahnerta (1958), ki mi je med srečanjem 17. junija 2009 v Gradcu povedal, da je najverjetneje edini v sorodstvu, ki ve za genealoško povezavo s polihistorjem. Pri tem je več kot zanimivo, da Friedrichov bratranec dr. Bruno Brandstetter (1893-1994), ki se je vse življenje ukvarjal z domoznanstvom in genealogijo, od svojih sorodnikov nikoli ni izvedel, da je Valvasor tudi njegov neposredni prednik, in sicer praded v sedmem kolenu. Tega podatka Brandstetter v svojem tipkopisnem delu, ki ga je pri častitljivih 95-ih letih razmnožil za širše sorodstvo (Brandstetter, Burgen und Schlösser), nima. Za Valvasorja kot prednika sta v začetku leta 2010 izvedela šele njegova priletna sinova.

${ }^{62}$ Njegovo življenje in delo je v letih po smrti faktografsko temeljito obdelal Stekl, »Die Tätigkeit,« $35-49$. 
svoj lepi tenor in se končno povsem posvetil glasbi. Preden je pri 36-ih nastopil službeno mesto v Ljubljani, je bil od leta 1902 dobro desetletje direktor glasbene šole v Knittelfeldu pri Judenburgu, kjer je glasbeno življenje postavil na docela nove temelje. ${ }^{63} \mathrm{~S}$ svojimi uspehi je nase opozoril širšo javnost in se 3. maja 1909 kot gostujoči solist Filharmonične družbe na Haydnovem spominskem koncertu prvič predstavil tudi ljubljanskemu občinstvu. ${ }^{64}$ Slaba štiri leta zatem je z dobrimi priporočili in bogatimi izkušnjami prišel v kranjsko prestolnico za direktorja Filharmonične družbe, kar je v njegovi karieri pomenilo velik korak naprej. ${ }^{65}$ Tudi za ljubljansko glasbeno življenje nasploh je njegov prihod - v začetku leta 1913 - predstavljal pomembno obogatitev. Starejši kolega Hans Gerstner ga je pomnil predvsem kot pevca. ${ }^{66}$ Vendar je bilo mlademu Rudolfu dano le poldrugo leto mirnega ustvarjanja, slabih 18 mesecev do izbruha prve svetovne morije. Kot bi Kranjski, domovini svojega znamenitega prednika, in z njo vsej Habsburški monarhiji simbolno zapel rekviem, je Rudolf šest tednov pred usodnimi sarajevskimi streli dirigiral v Ljubljani enega svojih vrhunskih koncertov. Pomenljivo je, da je šlo za izredni koncert ob proslavi stoletnice ponovne združitve Kranjske z Avstrijo 16. in 17. maja 1914! ${ }^{67}$

Nekaj mesecev zatem je moral von Weis-Ostborn, glasbeni direktor, učitelj na glasbeni šoli in uveljavljeni dirigent, obleči uniformo in oditi na fronto, v bran tiste Avstrije, $v$ katero je »Valvasorjeva« Kranjska sto let prej (1814), po koncu francoske zasedbe, vstopila drugič in - zadnjič. Med vojno Rudolfa skorajda ni bilo v Ljubljani, vodstvo glasbene šole in koncerte pa je namesto njega prevzel ostareli koncertni mojster in poznejši von Weis-Ostbornov naslednik Hans Gerstner. ${ }^{68}$ Direktorjeva dolgotrajna odsotnost pomaga pravilno razumeti tudi podatke o njegovem bivanju v Ljubljani, ki jih najdemo v evidenci prebivalcev mestne občine. Potem ko se je njegovo ime 10. januarja 1913 pojavilo na novi zglaševalni poli kot »Rudolf pl. Weiss Ostborn« s poklicem »glasbeni ravnatelj slov. filharmonije« (sic!), so ga tu skupaj z ženo Hermino, rojeno Kappel, s presledkom vodili dobrih pet let in pol. Oba sta imela vseskozi domovinsko pravico v Knittelfeldu, ženinem rodnem mestu, kjer sta se 19. septembra 1903 tudi poročila. Zakonca brez otrok sta v Ljubljani najprej živela pri Pollakovih na Dvornem trgu in nato še na dveh naslovih v hišah Kranjske hranilnice. ${ }^{69}$ Nagli odhod v rodni Gradec po Rudolfovi razrešitvi z direktorskega mesta konec aprila $1919^{70}$ jima očitno ni dopuščal, da bi urejala takšne formalnosti, kot je odjava bivališča na mestni občini.

${ }^{63}$ Budkovič, Razvoj glasbenega šolstva, zv. 1, 118; Kuret, Ljubljanska filharmonična družba, 397; Stek1, »Die Tätigkeit,« 35-39, 43.

${ }^{64}$ Kuret, Ljubljanska filharmonična družba, 366, 739.

${ }^{65}$ Prav tam, 397.

${ }^{66}$ Weiss, Hans Gerstner, 164.

${ }^{67}$ Kuret, Ljubljanska filharmonična družba, 411.

${ }^{68}$ Prav tam, 417.

${ }^{69}$ Njuno bivanje na prvem naslovu, v Gregorčičevi ulici, je izpričano za čas med 13. novembrom 1914 in 7. avgustom 1916, a je tu v glavnem prebivala le žena, medtem ko je bil Rudolf po večini na fronti. Na drugem naslovu, v Gradišču, sta se zakonca prijavila skoraj natanko dve leti pozneje, 10. avgusta 1918, nato pa iz zglaševalne pole ni razvidno, ne kdaj sta se odselila ne kam. Zgodovinski arhiv Ljubljana (= ZAL), LJU 500, Mestna občina Ljubljana, Domovinski oddelek, Zglaševalne pole mesta Ljubljane okrog 1900-1941 (1945), t. e. 258, MF 728.

${ }^{70}$ Kuret, Ljubljanska filharmonična družba, 445. 
Rudolf je torej v času šestletnega direktorovanja Filharmonični družbi v resnici preživel v Ljubljani manj kot polovico »službenih let«. Po slabih dveh letih bivanja na Kranjskem je moral jeseni 1914 obleči vojaško suknjo, ${ }^{71}$ vrnil pa se je nekako spomladi 1918 in preživel v kranjski, nato slovenski prestolnici še približno leto dni. ${ }^{72}$ Do jesenskega zloma monarhije je bival v Ljubljani kot oproščen vojaške službe (»kriegsdienstlich beurlaubt«) in spet v direktorski funkciji. ${ }^{73}$ Dogodki ob koncu vojne pa so ga, tako kot večji del podanikov monarhije, našli slabo pripravljenega na nove razmere. Zadnji simfonični koncert, ki ga je 18. oktobra 1918 še organizirala Filharmonična družba, bi spet lahko razumeli simbolno: nastopil je vojaški orkester iz Gradca, toda nastopajoči in občinstvo so bili z mislimi drugje: pri razpletu vojne in pri dva dni prej izdanem cesarjevem manifestu o preureditvi monarhije v zvezo narodnih državnih enot. ${ }^{74}$ Po skorajšnjem nastanku nove države čas tovrstnim koncertom ni bil več naklonjen. Mnogi člani in podporniki Filharmonične družbe so se po razpadu monarhije preselili v »Nemško Avstrijo«. Direktor von Weis-Ostborn je sprva še vztrajal na položaju, ki pa je kmalu postal nevzdržen tako za ustanovo kot zanj osebno. Obupan poziv Filharmonične družbe preostalim in potencialnim novim članom kaže, kako njeno vodstvo ni znalo razumeti novih časov. Ustanova, ki je od ustanovitve Glasbene matice (1872) dobivala vse bolj nemški predznak, je zdaj pozivala k ohranitvi »stare tradicije« in se sklicevala na »nemško čast«. Na njen poziv se je hitro odzvala nova oblast, ki je Filharmonično družbo marca 1919 spravila pod državni nadzor. ${ }^{75}$ Kakšna je bila drža direktorja in kakšno njegovo intimno razmišljanje, razpoložljivi viri ne povedo. ${ }^{76}$ Ali pač. Von Weis-Ostbornov medvojni namestnik, priletni Hans Gerstner, je v obširnem opisu delovanja družbe v prelomnem letu 1919 zapisal: »Potem ko glasbeni ravnatelj von Weiss-Ostborn spričo vladajočih okoliščin ni hotel več ostati v službi Filharmonične družbe, je bil na seji predsedstva 29. aprila 1919 dosedanji ravnateljev namestnik [...] Hans Gerstner soglasno imenovan za glasbenega ravnatelja $[\ldots] . .^{77}$ Gerstnerju je pred ukinitvijo Filharmonične družbe pripadla kratkotrajna vloga zadnjega ravnatelja ${ }^{78}$ von Weis-Ostborn pa naj bi se po navedbah K. Stekla že naslednji

${ }^{71}$ Budkovič, Razvoj glasbenega šolstva, zv. 1, 120, 125; prim. Kuret, Ljubljanska filharmonična družba, 417.

${ }^{72}$ Sredi maja 1918 je namreč na koncertu »v korist vojne preskrbe« nastopil z nekaj pesmimi, med drugim tudi z lastno skladbo (Kuret, Ljubljanska filharmonična družba, 439).

${ }^{73}$ Stek1, »Die Tätigkeit,« 42. - Budkovič, Razvoj glasbenega šolstva, zv. 1, 125, nedoločno navaja, da je na glasbeni šoli poučeval v šolskem letu 1917/18, potem ko je bil od jeseni 1914 v vojaški službi. Po spominih H. Gerstnerja je v tej sezoni nastopil na zadnjem od petih koncertov Filharmonične družbe, ker je bil ravno na dopustu (Weiss, Hans Gerstner, 163-164).

${ }^{74}$ Kuret, Ljubljanska filharmonična družba, 441.

${ }^{75}$ Prav tam, 442.

${ }^{76} \mathrm{O}$ usodi muzeja in arhiva Filharmonične družbe gl. prav tam, 448.

${ }^{77}$ Prav tam, str. 445. Prim. Weiss, Hans Gerstner, 69.

${ }^{78}$ Kuret, Ljubljanska filharmonična družba, 443. - V svojih spominih je Gerstner zapisal, da mu je direkcija Filharmonične družbe podelila naziv glasbenega direktorja »pozimi 1918-19, ko Weiss-Ostborn ni več opravljal dela glasbenega direktorja in je zapustil Ljubljano« (Weiss, Hans Gerstner, 170), kar pa je v nasprotju z drugimi viri (gl. prejšnjo in naslednjo opombo) in z navedbami v Gerstnerjevem lastnem sestavku o razpustu Filharmonične družbe (prav tam, 68). 
dan, 30. aprila 1919, vrnil v svojo »ožjo domovino«. Po poldrugem letu službovanja kot zborovodja v Groß-St. Florianu je 1. novembra 1920 nastopil svoje zadnje in obenem najdaljše službeno mesto: vse do leta 1956, ko je dopolnil 80 let, je ostal direktor stolničnega zbora v Gradcu. ${ }^{79}$

Klavrni konec ljubljanske Filharmonične družbe, ki je to stoletno ustanovo doletel zaradi obremenjenosti z nemško orientiranostjo in nove politične stvarnosti, je za glasbeno življenje na Slovenskem pomenil izjemno hud udarec, saj »pogrebci« Filharmonične družbe niso znali izkoristiti tradicije in mednarodnega ugleda družbe. ${ }^{80}$ Nasprotno je bilo vodenje ugledne ustanove odskočna deska v karieri njenega predzadnjega direktorja Rudolfa von Weis-Ostborna. Prikrajšan za direktorsko mesto v Ljubljani in za plemiški naslov je imel 43-letnik pred seboj še plodovita desetletja, v katerih je poleg vodenja graškega stolničnega zbora opravljal več drugih glasbeno-pedagoških in dirigentskih služb, od leta 1929 z naslovom profesorja. Kulturna javnost v Gradcu ga je dobro poznala, v zadnjih letih in po smrti pa so sledila tudi uradna priznanja. Zapustil je obsežen glasbeni opus, od cerkvene glasbe (številne maše, rekviem, zelo veliko ofertorijev in gradualov) preko ljudskih, klavirskih in zborovskih skladb do krone svojega ustvarjanja, velikega oratorija Christophorus (1947). ${ }^{81}$ Graška Weltpresse je skladatelja ob praizvedbi tega dela označila z besedami, ki jih je Weis-Ostbornov življenjepisec K. Stekl izbral tudi za konec biografskega prispevka o njem: »Znani graški glasbenik in skladatelj Rudolf Weis-Ostborn je doživel svoj dolgo pričakovani veliki dan. V njegovem pred desetimi leti končanem oratoriju se razkrijejo značilnosti, ki napolnjujejo njegovo bistvo in oplajajo njegovo ustvarjanje: globoka vernost srca, silen in uravnovešen domislek, izredno tehnično znanje in spoštljivo poznavanje velikanov pred njim [...]. Po mogočnem sklepu so se občinstvo in soustvarjalci združili v hvaležni počastitvi navzočega skladatelja. $^{82}$

Ni znano, ali se je priznani graški glasbenik po letu 1919 še kdaj vrnil v Ljubljano, rodno mesto svojega znamenitega prednika, pa četudi le na kak obisk ali zgolj mimogrede, če je potoval v to smer. Priložnosti mu vsekakor ni manjkalo, saj je potem, ko tu ni hotel oziroma mogel več ostati, živel še dobrih 43 let. Ljubljano je torej zapustil ravno na polovici svoje življenjske poti. Ni odveč omeniti, da se je po smrti prve žene (1949) 10. februarja 1951 ponovno poročil, in sicer z žensko, ki je imela bržkone slovenske korenine in bila skoraj pol stoletja mlajša od njega. ${ }^{83}$ Danes, pol stoletja po smrti Rudolfa von WeisOstborna, pa se je ponudila priložnost, da se s koreninami tega glasbenika in skladatelja, Valvasorjevega pravnuka v šestem kolenu, seznani tudi slovenska muzikološka javnost.

79 Stekl, »Die Tätigkeit,« 43-46.

${ }^{80}$ Kuret, Ljubljanska filharmonična družba, 449-453.

${ }^{81}$ Stekl, »Die Tätigkeit, « 43-46.

${ }^{82}$ Prav tam, 47.

${ }^{83}$ Še ne 25-letna Maria Kramar (1926-2007), hči železniškega uradnika, rojena v Donawitzu pri Leobnu, je bila pred tem pri Weis-Ostbornu gospodinja. S 75-letnim možem je preživela še dobro desetletje do konca njegove življenjske poti. - DAG, Matriken-Zweitschriften, Graz-Dom, Trauungen 1951, No. 8. - Pripis o poroki pri vpisu krsta: DAG, Altmatriken, Graz-St. Andrä, Taufbuch XI 1876-1880, str. 490. 


\section{Arhivski viri}

Arhiv Psihiatrične klinike Ljubljana

- G-4177, Mayer Karol

ARS = Arhiv Republike Slovenije

- AS 309, Zbirka zapuščinskih inventarjev Deželnega sodišča v Ljubljani: šk. 18, 39, 92

- AS 455, Zbirka likovnih del: št. 62

DAG = Diözesanarchiv Graz-Seckau

Altmatriken

- Graz-St. Andrä: Taufbuch XI 1876-1880

Matriken-Zweitschriften

- Graz-Dom: Trauungen 1951

NŠAM = Nadškofijski arhiv Maribor

Matične knjige

- Šentjur pri Celju: R 1806-1836

StLA = Steiermärkisches Landesarchiv, Gradec

- A. Dienersperg: K 2

- Bezirksgericht Graz I: D 117/1867

- Handschriften: Gruppe 2, Hss. 678, 803, 908, 919

$\mathrm{ZAC}=$ Zgodovinski arhiv Celje

- ZAC/0495, Krajevno sodišče gospoščine Blagovna: šk. 2

ZAL $=$ Zgodovinski arhiv Ljubljana

- ZAL, LJU 500, Mestna občina Ljubljana, Domovinski oddelek: Zglaševalne pole mesta Ljubljane okrog 1900-1941 (1945), t. e. 258, MF 728

ZAP $=$ Zgodovinski arhiv na Ptuju

- ZAP 70, Rokopisna zbirka: R-45

Župnijski urad Šentjur pri Celju

- Dr. Herbert Kartin, Župnija Šentjur pri Celju (tipkopis 1956)

\section{Časopisni vir}

»Iz Ljubljane.« Novice gospodarske, obrtniške in narodne 23, št. 16 (19. 4. 1865): 130-132.

\section{Avdiovizualni vir}

Žižek, Fran. Ipavci. RTV Ljubljana, 1976 (televizijska nadaljevanka).

\section{Uporabljena literatura}

Barle, Janko. »Ipavec, Benjamin.« V: Slovenski biografski leksikon, uredila Izidor Cankar in Franc Ksaver Lukman, zv. 1, 363-364. Ljubljana: Zadružna gospodarska banka, 1925-1932.

___ . »Ipavec, Gustav.« V: Slovenski biografski leksikon, uredila Izidor Cankar in Franc Ksaver Lukman, zv. 1, 364-365. Ljubljana: Zadružna gospodarska banka, 1925-1932.

___ Ipavci: Prilog k zgodovini slovenske pesmi. Ljubljana, 1909.

Brandstetter, Bruno. Burgen und Schlösser meiner Vorfahren in mütterlicher Linie und deren Verwandten in Steiermark, Kärnten und Krain. Chronik einer Grossfamilie. Gradec, 1988 (tipkopis). 
Budkovič, Cvetko. Razvoj glasbenega šolstva na Slovenskem. Zv. 1, Od začetka 19. stoletja do nastanka konservatorija. Ljubljana: Znanstveni inštitut Filozofske fakultete, 1992.

Cvetko, Igor. »Valvasor in njegov zvok.« V: Valvasorjev zbornik: Ob 300 letnici izida Slave vojvodine Kranjske: Referati s simpozija v Ljubljani 1989, ur. Andrej Vovko, 311-322. Ljubljana: Slovenska akademija znanosti in umetnosti, Odbor za proslavo 300 letnice izida Valvasorjeve Slave, 1990.

Flotzinger, Rudolf, ur. Musik in der Steiermark: Katalog der Landesausstellung 1980. Gradec: Referat der Steiermärkischen Landesregierung, 1980.

___ ur. Österreichisches Musiklexikon. Zv. 5. Dunaj: Verlag der Österreichischen Akademie der Wissenschaften, 2006.

Frank-Döfering, Peter. Adelslexikon des Österreichischen Kaisertums 1804-1918. Dunaj: Herder \& Co., 1989.

Geršak, Ivan. Ormoški spomini: Ob petindvajsetletnici Ormoške posojilnice in ob tridesetlenici svojega beležništva v Ormožu. Ljubljana: Ormoška posojilnica, 1902.

Golec, Boris. ॥'Der Hudič ist hier zu Hause' - med uboštvom, glasbo, portreti neznanih prednikov, shizofrenijo in evtanazijo. Usode zadnjih Valvasorjevih potomcev na Slovenskem v prvi polovici 20. stoletja in njihova kulturno-umetnostna zapuščina.« Zgodovina za vse 17 (2010): 51-100.

. »Neznano in presenetljivo o življenju, družini, smrti, grobu in zapuščini Janeza Vajkarda Valvasorja.« Zgodovinski časopis 61 (2007): 303-364.

. »Poti in stranpoti Valvasorjevih potomcev z velenjskega gradu: Kdaj arhivski viri (ne) lažejo?« Arhivi 34 (2011): 497-524.

. »Pozabljeni 'mali štajerski Valvasor' - polihistorjev potomec Franc vitez Gadolla (1797-1866).« Kronika 60 (2012): 23-78.

___ . »Trpljenje 'celjskega Wertherja', tosvetne skrbi njegovega sina in uvod v zaton njunega rodu: Spomini dveh Valvasorjevih potomcev baronov Dienersperg s Celjskega.« Zgodovina za vse 18, št. 1 (2011): 15-67.

—_— . »Valvasorjevo neznano potomstvo do današnjih dni.« Zgodovinski časopis 62 (2008): 351-383 (1. del); Zgodovinski časopis 65 (2011): 292-373 (2. del); Zgodovinski časopis 66 (2012): 46-114 (3. del).

___ . _Vojaška in častniška komponenta pri potomcih polihistorja Janeza Vajkarda Valvasorja (1641-1693) do danes: Zgodba neke razvejane slovensko-avstrijske plemiške rodbine.« V: Vojaki iz slovenskega prostora na tujih tleh v preteklosti, ur. Darja Mihelič in Matjaž Bizjak, 205-242. Ljubljana: Založba ZRC, Zgodovinski inštitut Milka Kosa ZRC SAZU, 2011.

Grdina, Igor. Ipavci. Zgodovina slovenske meščanske dinastije. Ljubljana: Založba ZRC, ZRC SAZU, 2001.

. Šentjur, Šentjur v času, čas v Šentjurju. Šentjur: Krajevna skupnost, 2002.

Kuret, Primož. Ljubljanska filharmonična družba 1794-1919: Kronika glasbenega življenja v stoletju meščanov in revolucij. Ljubljana: Nova revija, 2005.

Pertl, Eman. »Ipavci kot zdravniki.« V: Ob odkritju spomenikov skladateljem Ipavcem, ur. Janko Liška in Marjan Žagar, 23-32. Šentjur pri Celju: Sklad za postavitev spomenikov skladateljem Ipavcem, 1972.

Radics, Peter von. Johann Weikhard Freiherr von Valvasor (geb. 1641, gest. 1693). Mit 5 
Porträts und 15 anderen Abbildungen; samt Anhang, Nachtrag und der Genealogie der Familie Valvasor. Ljubljana: Krainische Sparkasse, 1910.

Schlossar, Anton, ur. Erzherzog Johanns Tagebuchaufzeichnungen von seinem Aufenthalte im Kurorte Rohitsch=Sauerbrunn und über seine Reisen in Untersteiermark aus den Jahren 1810, 1811 und 1812. Gradec: Leykam, 1912.

Stekl, Konrad. »Die Tätigkeit eines steirischen Musikdirektors: Rudolf von Weis-Ostborn.« V: Steirische Musikerjubiläen 1971: Festschrift, ur. Konrad Stekl in Wolfgang Suppan. Gradec: Akademische Druck- und Verlagsanstalt, 1971.

Weiss, Jernej. Hans Gerstner (1851-1939): Življenje za glasbo. Maribor: Litera, Pedagoška fakulteta, 2010.

Witting, Johann Baptist. Steiermärkischer Adel. Nürnberg, 1919-1921. Ponatis: Die Wappen des Adels in Salzburg, Steiermark und Tirol. Zv. 1. Siebmacher's großes Wappenbuch 28. Neustadt an der Aisch: Bauer \& Raspe, 1979.

\section{MUSIC PRODUCTION AND REPRODUCTION BY VALVASOR'S DESCENDANTS IN THE SLOVENIAN TERRITORY IN THE NINETEENTH CENTURY AND THE FIRST HALF OF THE TWENTIETH CENTURY}

\section{Summary}

The article deals with the until-recently unknown descendants of the Carniolan polymath Janez Vajkard Valvasor (1641-1693) that were connected one way or another to music production and reproduction in the Slovenian territory. They belonged to the last generations of the polymath's family to live in the Slovenian territory, stemming from all three branches of Valvasor's descendants that split in the 1770. In the mid-nineteenth century nearly all their members moved from Slovenian Styria to Graz, but each and everyone who has been documented to have engaged in music had spent at least part of their lives in the Slovenian territory. The Gadolla family from the Blagovna by Šentjur mansion entered Slovenian cultural history of the first half of the nineteenth century for its connections with the composers of the Ipavec family. From the second branch, the Dienersperg barons, came the first musically educated Valvasor's female descendant, whose life came to an end at Kog by Ormož. However, from the third and musically most engaged family branch of Vavasor's descendants came the famous Styrian composer Rudolf von WeisOstborn (1876-1962), the headmaster of Ljubljana's Philharmonic Society in 1913-1919. Note ought to be made that the branched-out descendants of Janez Vajkard Valvasor (about 250 persons to date) have been most closely connected to music of all arts.

Until the appearance of the composer Rudolf von Weis-Ostborn the entire knowledge of the musical life of Valvasor's descendants consists of scanty records. The earliest is the diary entry of the Archduke Johann of Habsburg from 1810 stating that upon his visit to the Gadolla mansion of Blagovna music was playing during dinner. At the Blagovna mansion the parents of the future Ipavec composers met soon afterwards and the families would remain in contact for years to come. Although the Blagovna mansion was a kind of an "abode of muses" and a "seat of scholarship", with respect to music, the Gadollas 
were above all companions and supporters of musical life. Thus, Valvasor's great-greatgreat-grandson, Knight Gadolla (1797-1866), the author of a comprehensive local study opus, became an honorary member of the Musical Society in Celje sometime by 1836 and his oldest daughter Josefine played piano in the 1850s and 1860s. The second and now extinct branch of Valvasor's descendants was much more dedicated to music. Franc Ksaver Baron Dienersperg (1773-1846), uncle of Franc Gadolla, wrote in his memoirs that his family moved from Dobrna to Graz in 1835, among other things in order for his two daughters to receive "proper instruction in French, dancing and piano". Dienersperg's granddaughter Antonija, married Kofler (1855-1908), completed her education at Vienna Conservatory and moved after the wedding to Kog by Ormož, where the only memory to have been preserved of her to date is that of the concert piano. The interest in music taken by the third branch of Valvasor's descendants manifested itself at the latest date. However, this branch made a greater entrance into the history of musical creativity than any other. Graz-born Angela Sterger (1844-1869), daughter of Valvasor's female descendant from Velenje Castle and a Carniolan lawyer, made her appearance in 1865 at a social event at the Carniolan provincial theatre with a solo by Gustav Ipavec, of which her grandson, following her account, wrote 123 years later. She married into an explicitly musical family, as her ennobled father-in-law, Josef von Weis-Ostborn or Weis von Ostborn (1806-1904) was a famous violinist and her husband Johann was a composer (1846-1906). Their son Rudolf von Weis-Ostborn (1876-1962, Graz) became a professional musician and, among others, ran Ljubljana's Philharmonic Society for six years (1913-1919), with longer interruptions due to the war and enlistment. After the dissolution of the monarchy and his return to his native Graz, Rudolf took over the leadership of the cathedral choir for thirty-six years. He left a vast musical opus, ranging from church music (numerous masses, requiem, as well as a great many of offertories and graduals) through folk, piano and choir compositions, to the crown of his creativity, the grand oratory Christophorus (1947). Rudolf von WeisOstborn is well known to Styrian music history as a performer of music and composer and is the most famous name of all Janez Vajkard Valvasor's descendants. 